\title{
Landslide reactivation susceptibility modeling in Iași Municipality
}

\author{
Nicușor NECULA ${ }^{1}$, Mihai NICULIȚÁ ${ }^{1}$ \\ ${ }^{1}$ Department of Geography, Faculty of Geography and Geology, Alexandru Ioan Cuza University of Iași, \\ Iași, Romania
}

Received 3 November 2017; Revised 20 November 2017; Accepted 10 December 2017

*Correspondence to: Mihai NICULIȚĂ, e-mail: mihai.niculita@uaic.ro

\begin{abstract}
Iași Municipality as other urban areas around the world has a long history of landslide activity which needs to be studied considering the urban sprawl. We performed a first landslide susceptibility modeling for Iași Municipality based on the AHP method using weights given by expert judgements regarding the influence of preparatory and conditional landslides factors (slope, ruggedness, lithology, historic landslide density and hydrogeology) and weights given by the historic landslide density over the factors. The landslide inventory was performed based on LiDAR data and aerial imagery using the geomorphological mapping of landslide elements. Using the landslide probability density function we have shown that the landslide inventory is valid and we have selected 411 landslides considered recent to be used for the validation. The resulted susceptibility show that the most susceptible to landslide reactivations are the hillslopes of cuesta hills with relict and old landslides, especially at the main scarp. Recent landslides are mainly scarp slumps or landslide body translational reactivations. The validation showed that almost $70 \%$ of recent landslides are located on high susceptibility areas. Future work to improve the susceptibility and extend it to hazard modeling is needed considering the long history of landslide reactivations from Iași Municipality and the slow evolution of old landslides like in Țicău neighborhoods.
\end{abstract}

KEYWORDS

Urban landslides; landslide inventory; landslide susceptibility; Analytical Hierarchy Process; Iași Municipality

\section{Introduction}

Landslides are geomorphologic processes (Cruden, 1991) characterized by the gravitational induced displacement of the earth/debris toward the base of slope through several mechanisms: fall, flow, sliding, toppling or spread (Cruden and Varnes, 1996; Hungr et al., 2014). These natural phenomena are activated by several triggering factors such as heavy rainfalls, earthquakes, volcanic eruptions, snow melting on 
slopes where preparatory (slope, geology) and conditional factors cause the instability. Also, the anthropic impact represents an important factor which leads to the (re)activation of landslides. Nowadays, due to the continuous expansion of the territory and infrastructure development, human activities meant to improve living conditions are having sometimes the opposite effect because the problem of landslides (Brabb, 1991) has not been treated with necessary importance. Thus, works undertaken for roads and railways development, land use changes, deforestations, mines and quarries exploitation, agriculture terraces construction lead to landslide occurrence through/ by incising the slope base, or by favoring the natural triggers.

To reduce the potential damage and economic losses (Schuster and Fleming, 1986; Kjekstad and Highland, 2009) in urban development and land use planning (Leighton, 1976; Záruba and Mencl, 1982; Alexander, 1986; Alexander, 1989; Alexander, 2005; Petley, 2009) a good support to provide information about landslides is given by landslide susceptibility maps. Susceptibility is the first stage in the process of hazard and risk evaluation (Crozier and Glade, 2005), through which is modeled the relative spatial probability for the occurrence of landslides in a given area (Cararra 1983; Guzzetti, 2006), considering previous information about landslides and their control factors (Carrara and Merenda, 1976; DeGraff, 1978; Kirschbaum et al., 2010; Klose, 2015). To extend the susceptibility into landslide hazard the temporal probability needs to be taken into account (Varnes et al., 1984; Guzzetti et al., 1999; Corominas et al., 2014).

To calculate the landslide susceptibility have been developed different methods, based on geomorphologic analyses and direct field observations as qualitative methods (Amadesi and Vianello, 1978; Aleotti and Chowdhury, 1999; van Westen et al., 2003), or which are relying on statistical models, probabilistic and deterministic approaches considered as quantitative methods (Carrara, 1983; Carrara et al., 1991; Ercanoglu, 2005). However, it cannot be said precisely which method is better, each one having their own advantages and disadvantages, for this reason recent studies attempts to combine these methods in order to obtain more precise information (Rossi et al., 2009). Another mandatory issue in susceptibility modeling is choosing the appropriate "mapping unit" and the appropriate method of sampling for statistical model fitting (Hussin et al., 2016), which allows the exploitation of ground conditions of the terrain (Guzzetti et al., 1999). For this reason, the selected approach is suitable only for study cases having specific environmental factors, the same methodology cannot be exploited in other regions as the result might not have the same reliability (Van Den Eeckhaut et al., 2009).

Considering the previous landslide reactivations which affected Iași city hillslopes (Macarovici, 1942; Băcăuanu, 1970; Martiniuc and Băcăuanu, 1982; Niculiță et al., 2017; Necula et al., 2017) multiple times during the last two centuries, landslide susceptibility modeling becomes an important tool to prevent future hazards related to the reactivations of old Holocene to Medieval Age landslides (Niculiță et al., 2016). The susceptibility map becomes a necessity for the urban development which can significantly reduce the economic costs and the damages to community (Leighton, 1976; Záruba and Mencl, 1982; Varnes et al., 1984; Alexander, 1986; Alexander 1989; Petley, 2009).

For this case study, the landslide susceptibility modeling has been realized using a probabilistic approach which is taking into account the environmental factors of the study area based on the Analytic Hierarchy Process (AHP). This method was chosen because although a landslide inventory was created, the landslide morphology was altered by human intervention (Barbu et al., 1987) and therefore cannot be used to train a more sophisticated statistical model. Also the landslide inventory is a geomorphological one and not a multi-temporal one, containing different age and magnitude landslides, the recent events that affected the city being mainly reactivations of old landslides.

\subsection{Study area}

Iași Municipality $\left(91.5 \mathrm{~km}^{2}\right)$ is located in the southern part of the Jijia Hills, at the contact with the Central Moldavian Plateau (Fig. 1). In the Jijia 
Hills the monoclinic geological structure (Brânzilă, 1999; Ionesi, 1994), the relative resistance of claystones and mudstones intercalated with sands and the homoclinal shifting of the Bahlui River and its tributaries toward south generated the development of cuesta landforms: the asymmetric hills and the structural valleys (Băcăuanu, 1968; Ioniță, 2000; Niculiță, 2011). The lithology (Fig. 2 and 3 ) is predominantly composed from claystones and mudstones with sandy intercalations (Brânzilă, 1999; Ionesi et al., 2005; Dill et al., 2011) which are comprised in two formations of Bessarabian age: Cryptomactra Clays Formation (outcropping under 125-150 m a.s.l.) and Bârnova-Muntele Formation (230 m thick formation outcropping over 125-150 m a.s.l.). The cuesta hills North and South of Bahlui River have the planar and gentle sloping dip hillslopes covered by fluvial deposits (gravels and clays 2 to $5 \mathrm{~m}$ thick) and loess (5 to $25 \mathrm{~m}$ thick) (Martiniuc and Băcăuanu, 1959; Martiniuc and Băcăuanu, 1966; Schram et al., 1977) and do not have altitudes going beyond $220 \mathrm{~m}$ a.s.l. (Rediu Hill, Copou Hill, Șorogari Hill, Galata Hill, Cetățuia Hill). Toward south, above the $200 \mathrm{~m}$ altitudinal boundary, in the Central Moldavian Plateau the presence of a caprock geological structure imposed the detachment of an escarpment which represents the Eastern part of the Iași Escarpment (Băcăuanu, 1968; Băcăuanu et al., 1980, Ungureanu, 1993) where the ridges altitudes are between 365 and 407 $\mathrm{m}$ a.s.l. (Repedea and Păun Hills). The caprock is represented by the Repedea Formation, composed from calcarenites, oolitic calcarenites and quartz arenites intercalated with sands and claystones (Jeanrenaud and Saraiman, 1995; Brânzilă, 1999; Ionesi et al., 2005; Dill at al., 2011) which outcrops predominantly in the Repedea Hill. Over the Bessarabian rocks, a $40 \mathrm{~m}$ thick Kersonian suite starts transgressively composed mainly from sands (Balta-Păun Formation) and outcrops in the Păun Hill.

\subsection{Landslide factors}

In North-Eastern Romanian lowland, respectively in the Moldavian Plateau, relict and old landslides (Upper Pleistocene to Holocene age) appear on almost all cuesta scarps and steep hillslopes (Niculiță and Mărgărint, 2014; Niculiță et al., 2016;
Mărgărint and Niculiță, 2017). Because of the dry climate (Pánek, 2015; Niculiță et al., 2017) the landslide morphology and deposits were smoothed by erosion and are very susceptible to landslide reactivations. Recent landslides which still have all the landslide morphologic elements not affected by erosion triggered under the current dry climatic conditions after the Medieval times (Niculiță et al., 2016).

The morphostructure, morphometry and the topography of the study area are favorable preconditioning factors to landslides development, especially for the steep cuesta escarpments (Mărgărint and Niculiță, 2017). The slope relation with the geological structure/rock stratification (Meentemeyer and Moody, 2000; Cruden and Eaton, 1987) on cuesta escarpments is anaclinal, with subdued relation (slope angle lower than the dip angle and the slope cuts perpendicular the bedding planes). The majority of the North, North-East and North-West facing hillslopes enter in this category. On Southern, South-Eastern and South-Western cuesta dip slopes the geological structure/rock stratification relation is cataclinal, the slopes being underdip (slope angle lower than the dip and the slope cuts along the bedding plane). Eastern and Western hillslopes are ortoclinal, the slopes cutting the bedding planes laterally. This morphostructure, combined with the presence of springs and aquifers at the base of the fluvial and loess/sandstone and limestone caprocks and along sand layers intercalated in the claystones and mudstones, is responsible for the great extension of the landslides along the steep hillslopes. The majority of landslides are soil/earth planar/translational slides (type 12 from Hungr et al., 2014 extension of Cruden and Varnes, 1996 classification) developed on the steep slopes under the influence of river incision and lateral migration toward the hillslopes base. On old landslide scarps rotational soil/earth slumps are frequent (type 11). Old landslide deposits with a mixture of clays, silts and sands have flowslides and earthflows (type 20 and 26). On the western and northern hillslopes of Repedea and Păun Hills also compound slides appear (type 14) as multiple retrogressive compound slides due to the retrogressive evolution of the hillslopes under the influence of river incision (Niculiță et al., 2016). Very often complex landslides appear on the steep 
hillslopes as a combination of multiple mechanisms and the overlay/amalgamation (Marc and Hovius, 2015; Samia et al., 2017) of different age events, generating continuous landslides which cover the hillslope on lengths of up to $2-3 \mathrm{~km}$ (the Eastern hillslope of Copou Hill, both Western and Eastern hillslopes of Șorogari Hill, and the Western hillslope of Aroneanu Hill).

Almost all steep hillslopes (Fig. 4) from Iași Municipality area are covered by such complex landslides, that is why landslide reactivations are quite frequent (Samia et al., 2017) especially during spring time or summer time under heavy rainfall
(Mărgărint and Niculiță, 2017; Niculiță et al., 2017). During the last two centuries, the magnitude of reactivations decreased also because remedial measures were carried out (Consiliul Județean Iași, 2012; Necula et al., 2017): passive mechanic infrastructure, drainages and protection forests. Despite the remedial measures such areas are in a slow moving state (like the case of North-Eastern hillslope of Copou Hill where there is a velocity of the slow moving landslide of up to $1.8 \mathrm{~cm} /$ year Necula et al., 2017).

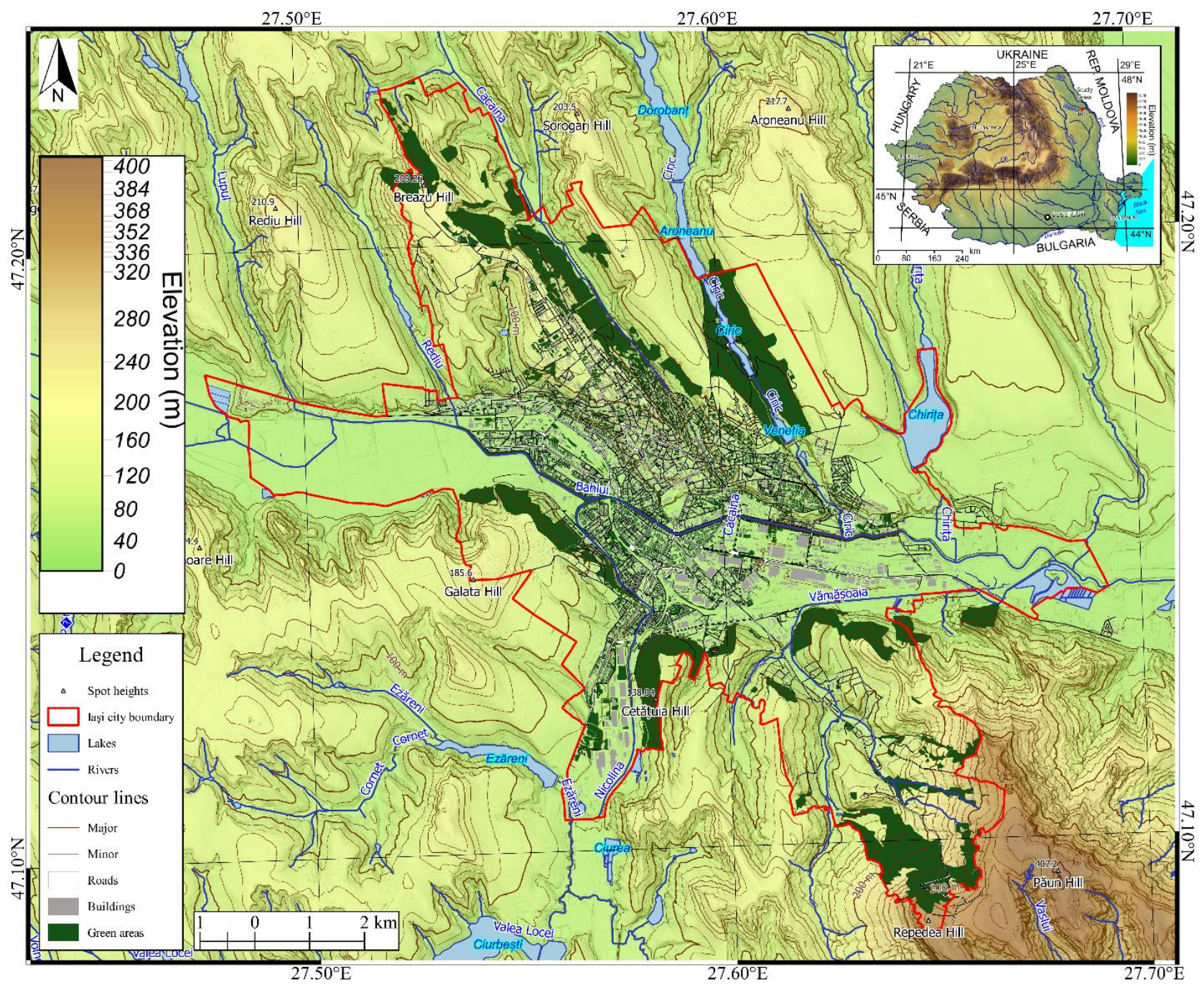

Figure 1 Geographical background of Iași Municipality. 


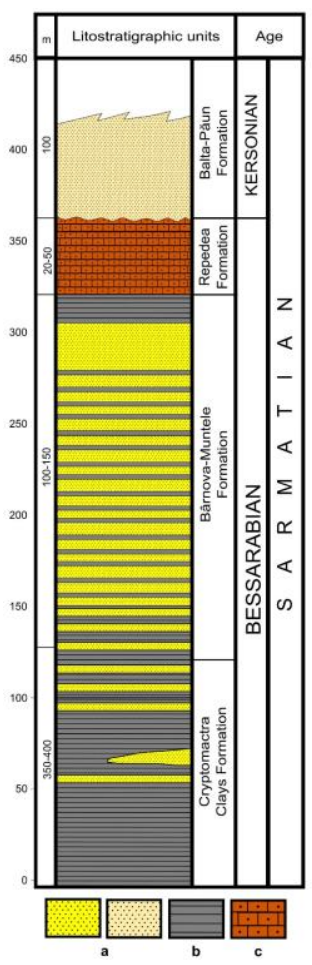

Figure 2 Lithostratigraphic column of the Bessarabian and Kersonian in Repedea Hill (compiled after Brânzilă, 1999; Ionesi et al., 2005): a - sands, b - claystones and mudstones, c - limestones.

Although the area has a dry climate, maximum 24 hour rainfall amount can go beyond $100 \mathrm{~mm}$ (Mărgărint and Niculiță, 2017; Niculiță et al., 2017). Historical rain trends also show a very humid period during the $70^{\prime}$ and $80^{\prime}$ which might repeat after a 30/40 year cycle (Niculiță et al., 2017). Areas with reactivations are known for Iași Municipality in the following locations: the Copou Hill north-eastern hillslope (1932-1933, 1940-1942, 1969-1970, 1984; 2017), for Șorogari Hill western hillslope (19691970), for Galata Hill northern hillslope (1979), Cârlig Hill western hillslope (1981), for Cetățuia (1980) and for Bucium area (1973) as reported by various authors (Macarovici, 1942; Băcăuanu, 1970; Martiniuc and Băcăuanu 1982; Schram et al., 1977). In recent times (after the 90') landslide reactivations were reported in Munteni Neighborhood, Cimitirul Evreiesc, Grădina Botanică, Șapte Oameni Street, Aleea Sadoveanu, Cetățuia (Consiliul Județean Iași, 2012). Although there are remedial measures applied to the most active areas of landslide reactivations constructed especially before the 90' the failure to maintain them makes it difficult to estimate which is the level of protection which these measures assure for the future rainy periods.

\section{Materials and methods}

\subsection{Materials}

The historical map sources (1:20 000, 1:5 000, 1:2 000 topographic maps from the 1920-1960 period), Google satellite imagery archive (2003-2017), aerial imagery (1956-1964, 1971-1984, 2005, 2008) and a $0.5 \mathrm{~m}$ spatial resolution LiDAR DEM acquired in 2012 were used for the creation of a geomorphological landslide inventory (Carrara et al., 2003; Guzzetti, 2006; Guzzetti et al., 2012). Texture data from the aerial imagery and the LIDAR shading were supplemented by the use of the elevation derivatives (slope, curvature) and contours for the landslide delineation (Fig. 4) and typology assignation (Fig. 3).

For the susceptibility modeling environmental factors we have used the following layers aggregated to $5 \mathrm{~m}$ rasters (Fig. 5 and Fig. 6):

- Slope (Fig. 6a): computed from the LiDAR DEM at $5 \mathrm{~m}$ resolution using the algorithm of Wood (1996; 2009) in SAGA GIS (Conrad et al., 2015) using a kernel window of 3 by 3 pixels;

- Ruggedness (Fig. 6b): computed with the algorithm described by Riley et al., (1999) using a $5 \times 5$ pixels kernel window in SAGA GIS (Conrad et al., 2015); this parameter is a measure of both vertical and horizontal dissection of landforms and better describe the fluvial dissection compared with drainage density where the source of drainage data can be biased (Mark, 1983; Niculiță, 2012);

- Geology (Fig. 3): compiled after the 1:200 000 Geological Map of Romania, Saulea et al., 1966, completed with maps and information from Martiniuc and Băcăuanu, 1959, Martiniuc and Băcăuanu, 1966, Schram et al., 1977, Brânzilă, 1999, Ionesi et al., 2005 and slightly reshaped to match the LiDAR DEM resolution and features; 


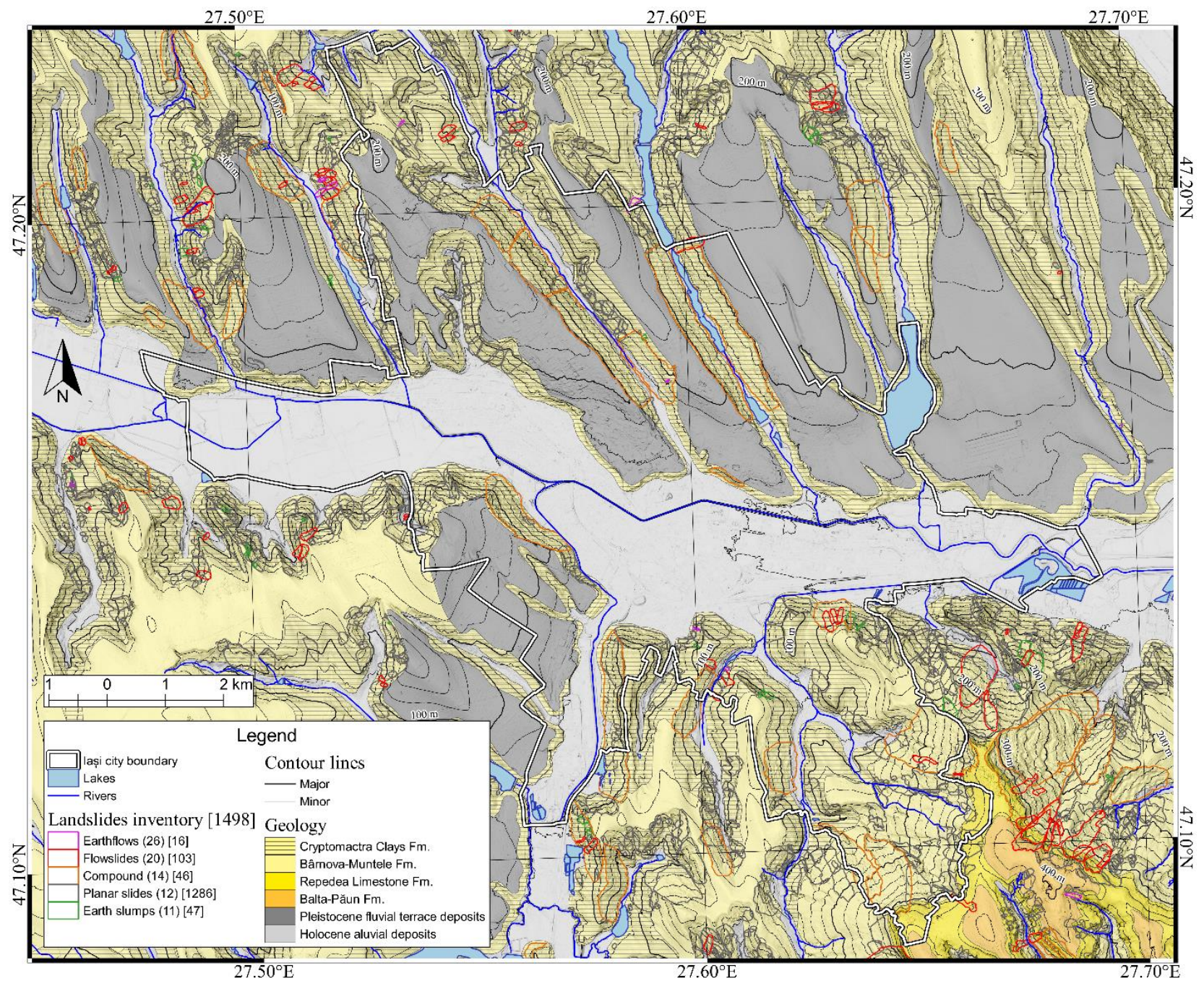

Figure 3 Geologic map of Iași surroundings (compiled after the 1:200 000 Geological Map of Romania, Saulea et al., 1966, completed with maps and information from Martiniuc and Băcăuanu, 1959, Martiniuc and Băcăuanu, 1966, Schram et al., 1977, Brânzilă, 1999, Ionesi et al., 2005) with the landslides inventory styled by landslide type.

- Landslide density (Fig. 6c): computed as a standardized value between 0 and $n$, where $n$ is the maximum number of landslides that overlap for the same pixel area; for the unaffected pixels values between 0.9 and 0.1 were computed based on their Euclidean distance to the closest landslides;

- Hydrogeology (Fig. 6d): digitized from a map of phreatic level for Iași Municipality (Schram et al., 1977) and expressed as the depth of the phreatic level under the topography level, the type of the surficial deposit (ridge, hillslope, fluvial) and the presence of springs.

Land use was not used as a predictable factor because the entire study area has urban features and the urban pressure on landslides is done in multiple ways that cannot be synthetized in a geospatial layer: water infiltration from broken urban water and sewage network, remedial measures which are degraded, heavy transport traffic, residential house extension and improvement.

\subsection{Methods}

The landslide inventory is a geomorphological one, containing all the landslides that were depicted from the remote sensing images and validated by the field observations (Carrara and Merenda, 1976; McCalpin, 1984; Wieczorek, 1984; Cararra et al., 2003; McKean and Roering, 2004; Guzzetti, 2006; Guzzetti et al., 2012). 


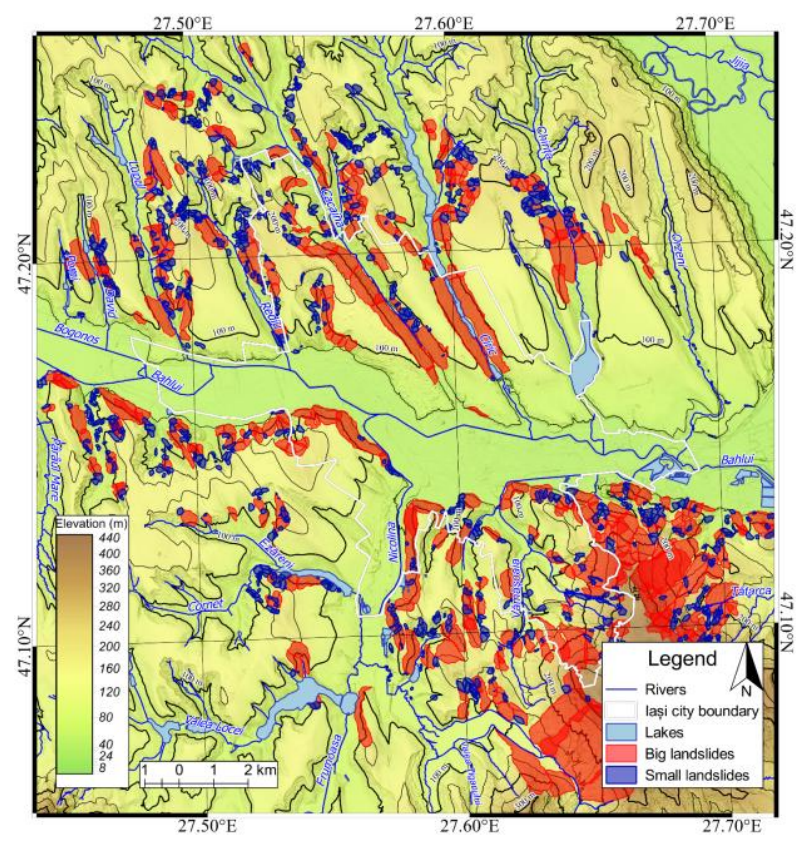

Figure 4 Landslides inventory.

While we recognize the limitations of the inventory, especially regarding the presence of relict or old landslides (Niculiță et al., 2016) we believe that this inventory can be used for susceptibility assessment. We used the inventory for assessing the weights which were given to environmental factors in the analytical hierarchy process. The landslide inventory was performed for an area bigger than the actual boundary of Iași Municipality in order to better assess the regional pattern of landslide activity. The landslide frequency density curve was computed using LANDSTAT R stat (R Development Core Team, 2008) script developed by Rossi et al. (2012).

The landslides (1498 in total) were delineated on LiDAR DEM only when at least two of the following landslide elements were identified on LiDAR (Carrara and Merenda, 1976; Varnes, 1978; McCalpin, 1984; Wieczorek, 1984; Varnes et al., 1984, Soeters and Van Westen, 1996; Cruden and Varnes, 1996; McKean and Roering, 2004; Van Den Eeckhaut et al., 2005; Ardizzone et al., 2007; Jaboyedoff et al., 2012; Petschko et al., 2015): (i) main scarp, other minor scarps or the crown, (ii) landslide flanks, (iii) landslide toe, (iv) landslide body with various wavelengths of ruggedness. The use of various shading methods and the 3D anaglyph stereoscopic plotting of the DEM in SAGA GIS greatly improved the mapping.
AHP is a semi-quantitative statistical method which is used for decision making processes using the score given by weights which are obtained using pairwise relative judgements of comparison between the considered factors (Saaty, 1977, 1980, 1987). The factors can be structured in hierarchical networks and the judgements generate a pairwise comparison matrix. The judgments are made based on a scale from $1 / 9$ (considered extremely less important) to 9 (considered extremely more important), a value of 1 meaning equal importance (Fig. 7). For example slope is considered to be 7 times more important (very strong) than hydrogeology (Table 1).

The main advantage of the method is the flexibility of its usage in resolving decision making processes using heuristic judgements and the possibility of checking the consistency of the judgements using the consistency index (Table 1). The main disadvantage is the subjectivity of comparisons and of the used factors (Table 2).

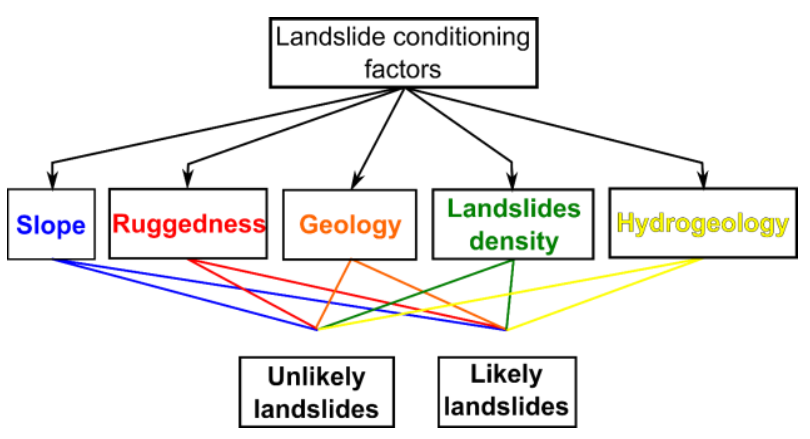

Figure 5 Graphical depiction of the AHP model.

This model was used as a trade-off between the pure heuristic (like geomorphological mapping) and the pure statistical methods (data mining of environmental factors where multicollinearity introduces irrelevant information) given the conditions of an urban area where landslides have different ages and are smoothed and influenced by the human activities.

AHP has been widely used for landslide susceptibility (Barredo et al., 2000; Ayalew et al., 2005; Yoshimatsu and Abe, 2006; Gorsevski et al. 2006; Yalcin, 2008; Wu and Chen, 2009; Akgun and Türk, 2010; Rozos et al., 2011; Akgun, 2012; Hasekioğullari and Ercanoglu, 2012; Mondal and Maiti, 2012; 


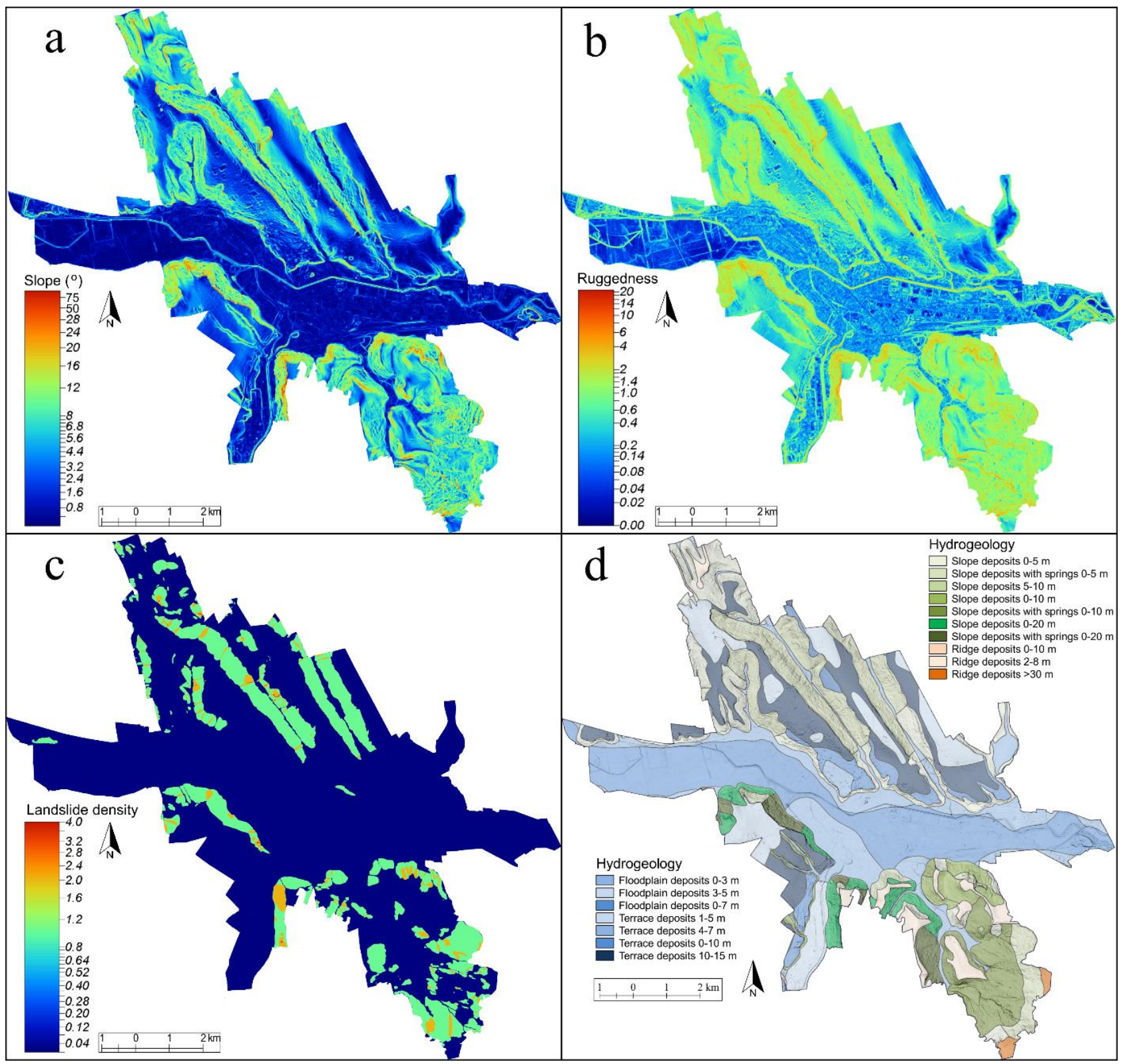

Figure 6 AHP factors: a) slope, b) ruggedness, c) historical landslide density, d) hydrogeology.

Pourghasemi et al., 2012). AHP statistics were computed with the $\mathrm{R}$ stat software (R Development Core Team, 2008) ahp package (https://cran.rproject.org/web/packages/ahp/index. html). The prediction was assessed using Chung and Fabri (1999, 2003) prediction rate curve. For the success curve we have used the plot of percentage of observed landslides susceptibility versus the percentage of susceptibility values over the entire map (Castellanos Abella, 2008). The class intervals, used for expressing the susceptibility outcome, were computed using the classInt package (https://cran.rproject.org/web/packages/classint/index.html) for $\mathrm{R}$ stat with the k-means clustering method.

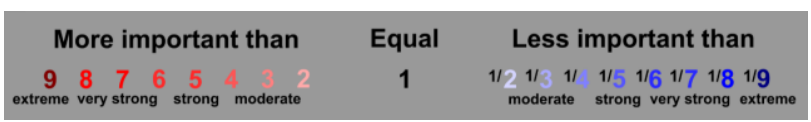

Figure 7 The scale used for judgement pairwise comparisons. 
Table 1 AHP environmental factors pairwise comparison matrix, weights and consistency index

\begin{tabular}{|c|c|c|c|c|c|c|}
\hline FACTOR & Slope & Ruggedness & Geology & $\begin{array}{l}\text { Landslide } \\
\text { densitv }\end{array}$ & Hydrogeology & Weight \\
\hline Slope & 1 & 3 & 4 & 5 & 7 & 0.54 \\
\hline Ruggedness & 0.33 & 1 & 3 & 5 & 6 & 0.24 \\
\hline Geology & 0.25 & 0.33 & 1 & 2 & 5 & 0.11 \\
\hline Landslide density & 0.20 & 0.20 & 0.50 & 1 & 4 & 0.07 \\
\hline \multirow[t]{2}{*}{ Hydrogeology } & 0.14 & 0.17 & 0.20 & 0.25 & 1 & 0.04 \\
\hline & & & & & $\mathrm{Cl}^{*}$ & 0.04 \\
\hline
\end{tabular}

*Consistency index

Table 2 Factor weights

\begin{tabular}{|c|c|c|c|c|c|c|c|c|c|c|}
\hline \multicolumn{2}{|c|}{ Slope } & \multicolumn{2}{|c|}{ Ruggedness } & \multicolumn{2}{|l|}{ Geology } & \multicolumn{2}{|c|}{$\begin{array}{l}\text { Landslide } \\
\text { density }\end{array}$} & \multicolumn{3}{|c|}{$\begin{array}{l}\text { Hydrogeology (deposit } \\
\text { and phreatic level depth) }\end{array}$} \\
\hline $\mathrm{C}^{*}$ & $\mathbf{W}^{* *}$ & C & W & C & $\mathbf{W}$ & C & $\mathbf{w}$ & deposit & C & w \\
\hline $0-1$ & 0.02 & $0-0.15$ & 0.02 & $\begin{array}{l}\text { Cryptomactra } \\
\text { Clays Fm. }\end{array}$ & 0.40 & 4 & 0.50 & \multirow{4}{*}{$\begin{array}{l}\text { Hillslopes } \\
\text { with } \\
\text { springs }\end{array}$} & $0-5$ & 0.18 \\
\hline $1-3$ & 0.03 & $\begin{array}{c}0.15- \\
0.5\end{array}$ & 0.03 & $\begin{array}{c}\text { Bârnova- } \\
\text { Muntele Fm. }\end{array}$ & 0.24 & 3 & 0.26 & & $0-10$ & 0.14 \\
\hline 3-7 & 0.05 & $0.5-0.8$ & 0.05 & Repedea Fm. & 0.16 & 2 & 0.13 & & $0-20$ & 0.11 \\
\hline $7-10$ & 0.07 & $0.8-1$ & 0.07 & Balta-Păun Fm. & 0.10 & 1 & 0.07 & & $0-5$ & 0.10 \\
\hline $10-15$ & 0.10 & $1-1.5$ & 0.10 & $\begin{array}{c}\text { Pleistocene } \\
\text { (terrace } \\
\text { deposits) }\end{array}$ & 0.06 & 0 & 0.03 & \multirow{4}{*}{$\begin{array}{c}\text { Hillslopes } \\
\text { without } \\
\text { springs }\end{array}$} & $5-10$ & 0.06 \\
\hline $15-20$ & 0.15 & $1.5-10$ & 0.15 & $\begin{array}{l}\text { Floodplain } \\
\text { deposits }\end{array}$ & 0.04 & & & & $0-10$ & 0.06 \\
\hline $20-30$ & 0.23 & $10-20$ & 0.23 & & & & & & $0-20$ & 0.05 \\
\hline \multirow[t]{10}{*}{$>30$} & 0.35 & $>20$ & 0.35 & & & & & & 4-7 & 0.05 \\
\hline & & & & & & & & \multirow{4}{*}{ Terrace } & $0-10$ & 0.04 \\
\hline & & & & & & & & & $10-15$ & 0.04 \\
\hline & & & & & & & & & $>15$ & 0.04 \\
\hline & & & & & & & & & $2-8$ & 0.03 \\
\hline & & & & & & & & \multirow[t]{3}{*}{ Ridge } & $0-10$ & 0.03 \\
\hline & & & & & & & & & $>\mathbf{3 0}$ & 0.02 \\
\hline & & & & & & & & & $0-3$ & 0.02 \\
\hline & & & & & & & & \multirow[t]{2}{*}{ Floodplain } & $0-7$ & 0.02 \\
\hline & & & & & & & & & 3-5 & 0.01 \\
\hline
\end{tabular}




\section{Results and discussion}

The landslide inventory contains 1498 landslides, with the area ranging from $226 \mathrm{~m}^{2}$ to $3.9 \mathrm{mil} \mathrm{m}^{2}$. The frequency density distribution of the area can be seen in Fig. 8 (red line), where there are plotted also two other curves for the Moldavian Plateau, one for an inventory which cover the entire Moldavian Plateau (black line) and one for a catchment from the Central Moldavian Plateau (blue line).

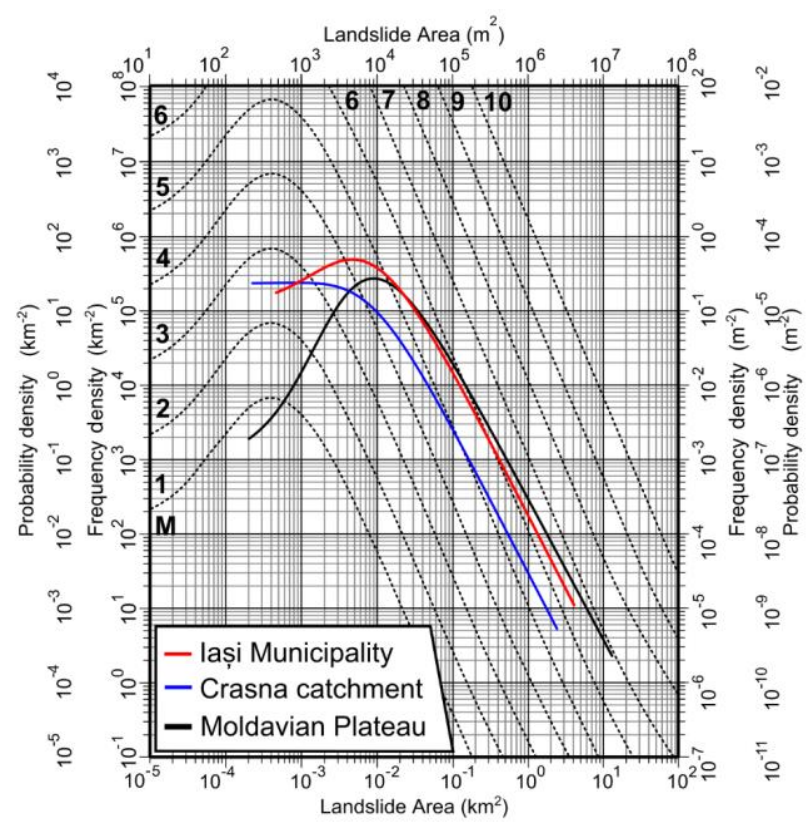

Figure 8 Landslide inventory area frequency distribution for Iași Municipality (red line), Crasna Catchment (blue line

- Bejenaru and Niculiță, 2017) and for the Moldavian

Plateau (black line - Mărgărint and Niculiţă, 2017).

The tail of the curve for Iași Municipality is very similar with the one for the Moldavian Plateau, showing that for big landslides the inventory contains the representative magnitudes. The shape of the distribution curve is also similar with other historic and geomorphologic landslides inventories (Malamud et al., 2004a, 2004b). For smaller landslides, the Iași Municipality inventory is more complete, and this is the reason why we use these landslides for validation. We define small landslides as the landslides that have under $50000 \mathrm{~m}^{2}$ (Fig. 4 blue polygons). This value was chosen by analyzing the frequency of landslide area and by investigating the morphology of these landslides on LiDAR DEM. The small landslides have a fresh morphology and have recognizable all the landslide features, thus being considered recent and only 200 to 300 years old (Niculiță et al., 2016).

The histogram of the susceptibility results can be seen in Fig. 9 and the spatial distribution of susceptibility values in Fig. 10. The distribution is lognormal and the k-means derived class intervals are $0,0.01,0.2,0.35,1$.

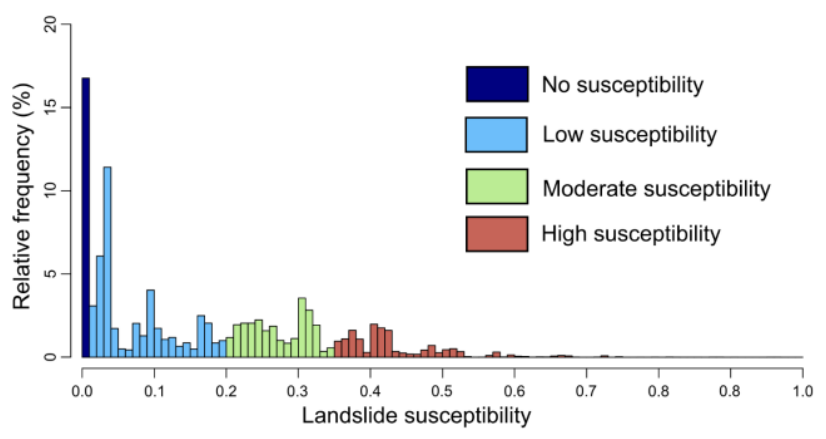

Figure 9 Landslide susceptibility histogram.

The four classes were labeled as no susceptibility (22.6\%), low susceptibility (40.7\%), moderate susceptibility (23.7 \%) and high susceptibility (13\%). The recent landslides cover $3.1 \%$ of the Iași Municipality territory, while all the mapped landslides cover $20 \%$. From the area covered by landslides, the susceptibility has the following statistics: $0.1 \%$ low susceptibility, $1.2 \%$ moderate susceptibility and $1.8 \%$ high susceptibility. No landslides appear in the area modelled as no susceptibility. For validation we have used the recent landslide inventory (411 landslides) and we derived the prediction rate curve and the success rate curve (Fig. 11). These curves show us that the model performed well and that the modelled susceptibility can explain reasonably well the recent landslide occurrence in Iași Municipality, $70 \%$ of all small landslides being located in $38 \%$ of the areas with high susceptibility values. If we compute mean susceptibility values for the recent landslide polygons, all of them have lower to high susceptibility values: 6 low susceptibility (0.3\%), 124 moderate susceptibility (30.5\%) and 281 high susceptibility (69.2\%).

The newest landslide from Iași municipality is represented by the scarp reactivation of the North-East hillslope of Copou Hill in the Ursulea area in May 2017. The scarp was affected on $150 \mathrm{~m}$ by a 


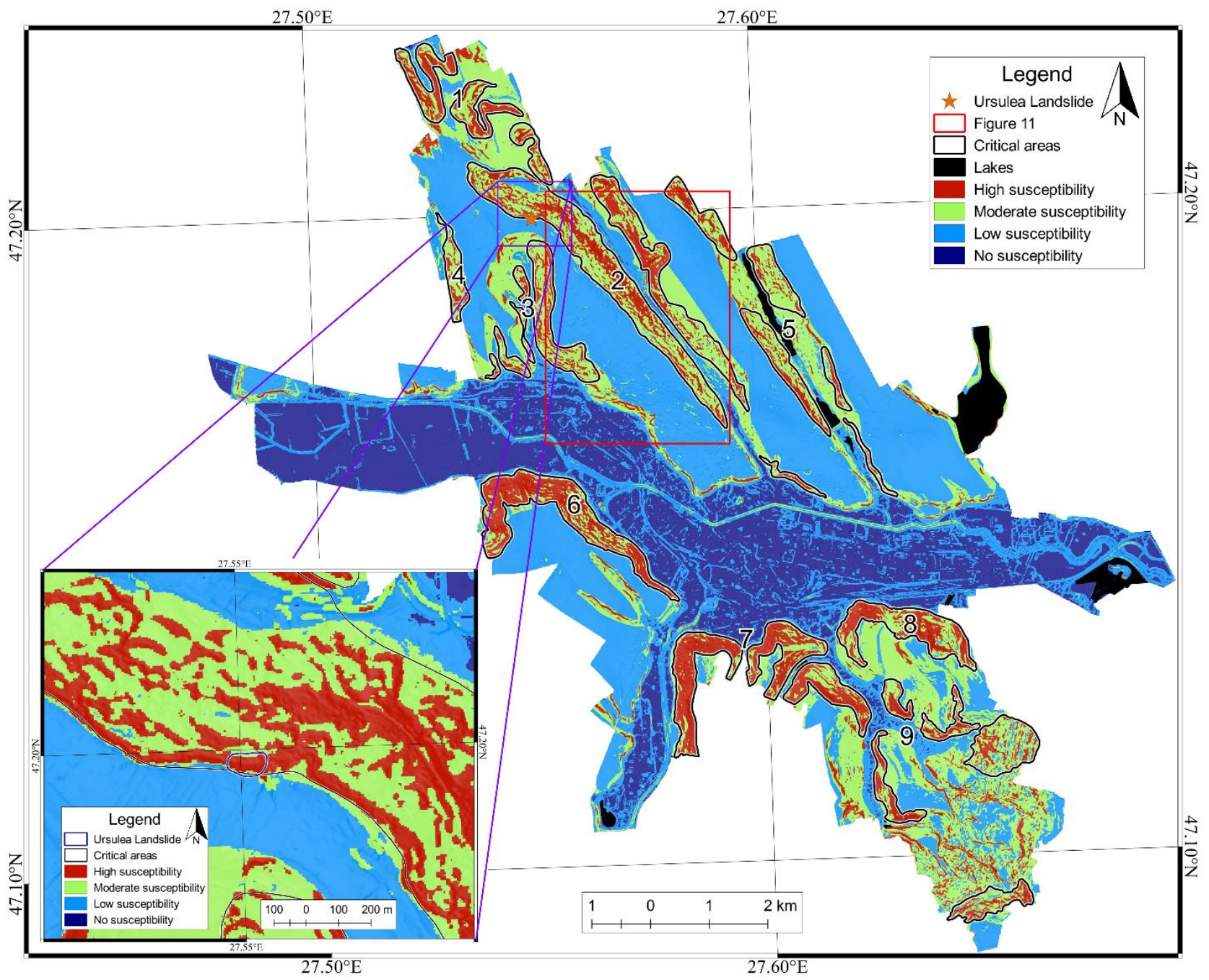

Figure 10 Landslide susceptibility map for Iași Municipality (numbers represent the areas that have the highest frequency of high susceptibility and are discussed in section 3); in inset the susceptibility in the Ursulea landslide area.
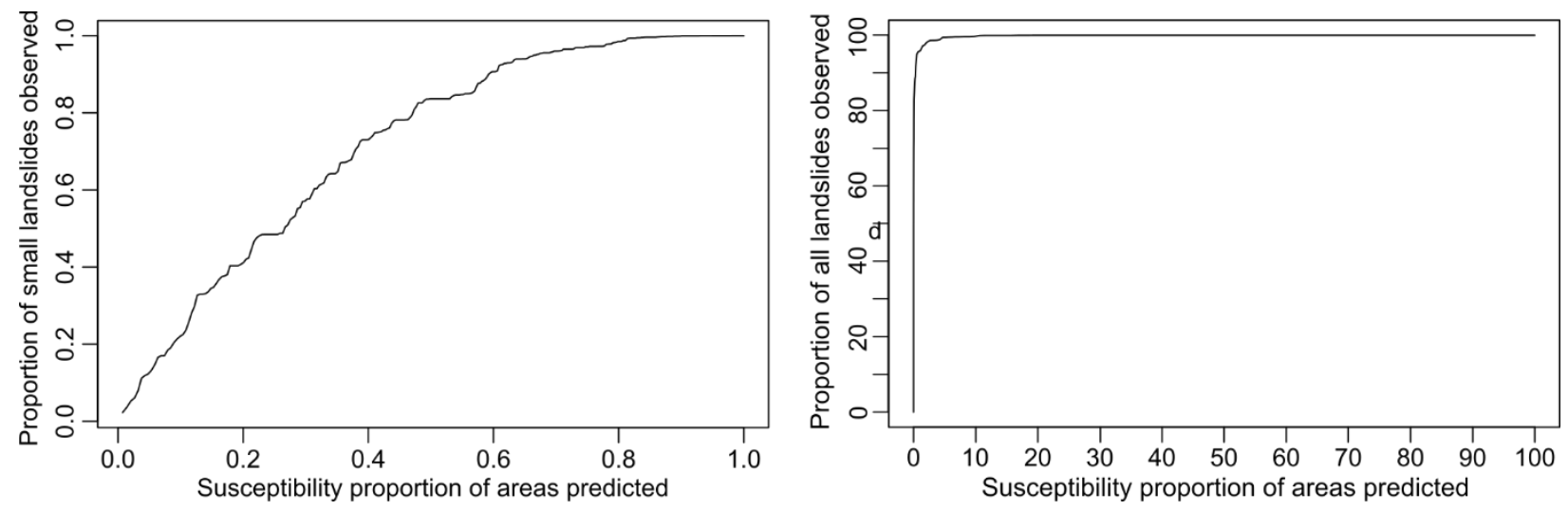

Figure 11 Landslide susceptibility prediction rate curve (left) and success curve (right). 
slump which has slided along $60 \mathrm{~m}$. On the modeling the location of the slump is considered to be an area of high susceptibility (the star from Fig. 10). Considering the location of this landslide we can say that scarp areas with high susceptibility are the most susceptible to reactivation, especially

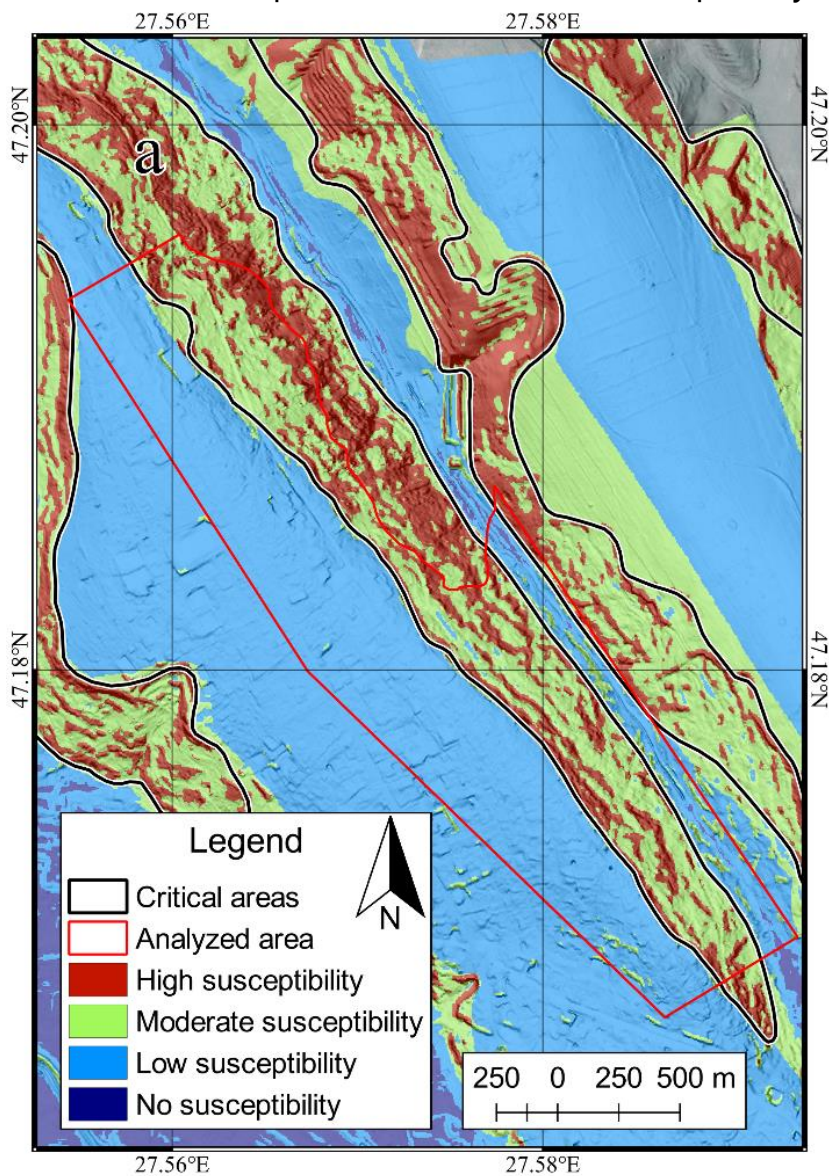

where upslope the scarp, the flat ridge edge has constructions. We considered also the Ticău neighborhood as a validation site (Fig. 12), the area having a high frequency of high susceptibility areas. The area has registered deformations for the 20142017 time interval (Necula et al., 2017).

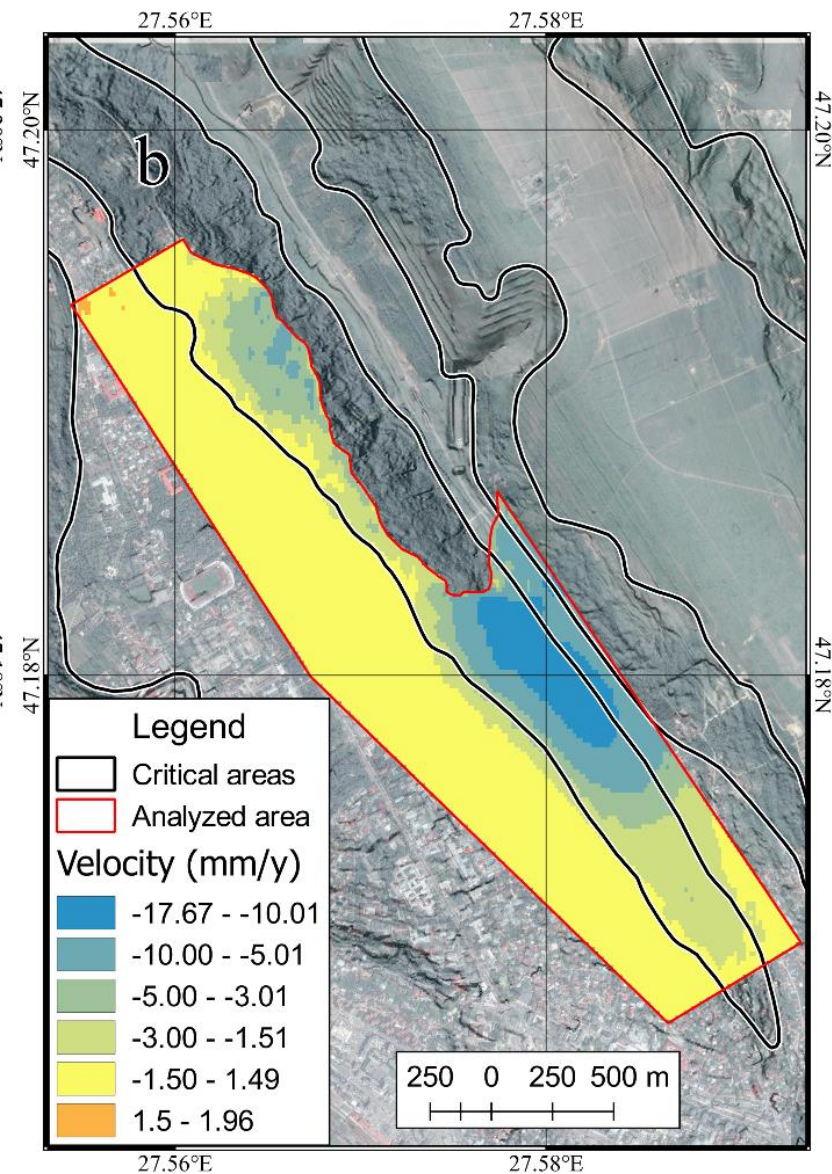

Figure 12 Landslide susceptibility for Țicău area on north-eastern Copou Hillslope (area 2 from Fig. 10) (a) and the velocity found by Necula et al., 2017 using INSAR (b).

Moderate and high susceptibility values are typically characteristic for the steep hillslopes of the cuesta escarpments, especially those who are affected by relict or old landslides. Low susceptibility values are characteristic for the cuesta dipslopes and flat ridges/plateaus, where especially the marginal areas are susceptible to landsliding through retrogressive slumps. The area without susceptibility to landslides covers the flat areas of the Bahlui floodplain and its tributaries. Low and moderate susceptibility appears on the Bahlui River bank levees where a bank failure happened in the beginning of June 2015. The low susceptibility values that appear on the Bahlui floodplain are related to anthropic features like road, bridge and building embankments.

We have delineated in Fig. 10 the areas (noted from 1 to 9) which have the biggest frequency of high susceptibility and we consider these areas as critical regarding the necessity of taking into consideration the hazard and risk modeling in any future planning activities of these areas. These areas are similar with those identified by the Consiliul Județean Iași (2012) assessment. Copou NorthEastern Hillslope (2), Botanical Garden area (3), Munteni neighborhood (4), Galata Hill (6) and Bucium Hills (9) are areas where the landslide reactivations were frequent during the last 100 
years. Beside these, areas like Breazu (1), Ciric (5) and Cetățuia-Vișani (7) are areas of post-communist urban sprawl which are prone to landslide reactivations.

\section{Conclusions}

Regarding the problem of landslide susceptibility in Iași Municipality we performed an initial modeling based on a semi-heuristic and semi-statistic method (AHP). The weights were given by expert judgements regarding the influence of preparatory and conditional landslides factors: slope, ruggedness, lithology, historic landslide density and hydrogeology. The weights for the factor values were derived from the historic landslide density over the used factors.

The results show that the most susceptible to landslide reactivations are the steep hillslopes of cuesta hills with relict and old landslides, which have high and moderate susceptibility. High susceptibility areas are especially in the main scarp area. The gentle dip-slopes and the flat ridges have low susceptibility, while the floodplains have no susceptibility.

The recent landslides used for validation are mainly scarp slump or landslide body translational reactivations. The validation showed that almost $70 \%$ of recent landslides are located on high susceptibility areas. Future work is needed to improve the susceptibility and extend it to hazard modeling since the Iași Municipality has a long history of landslide reactivations and the slow evolution of old landslides like in Ticău neighborhood could be amplified by future climatic changes or intense human pressure (like in the areas where the urban sprawl is intensive and landslide susceptibility is high).

\section{Acknowledgement}

We are grateful to Mauro Rossi who kindly provided us the script for computing landslide area density. We are grateful to Prut-Bârlad Water Administration who provided us with the LIDAR data. We have used the computational facilities given by the infrastructure provided through the POSCCE-O 2.2.1, SMIS-CSNR13984-901, No. 257/28.09.2010 Project, CERNESIM (L4).

\section{References}

Akgun A. 2012. A comparison of landslide susceptibility maps produced by logistic regression, multi-criteria decision, and likelihood ratio methods: a case study at Izmir, Turkey. Landslides 9: 93-106. DOI: 10.1007/s10346-011-0283-7

Akgun A, Türk N. 2010. Landslide susceptibility mapping for Ayvalik (Western Turkey) and its vicinity by multicriteria decision analysis. Environmental Earth Science 61: 595-611. DOI: 10.1007/s12665-009-0373-1

Aleotti P, Chowdhury R. 1999. Landslide hazard assessment: summary review and new perspectives. Bulletin of Engineering Geology and the Environment 58(1): 21-44. DOI: $10.1007 / \mathrm{s} 100640050066$

Alexander ED. 1986. Landslide damage to buildings. Environmental Geology and Water Science 8: 147-51. DOI: 10.1007/BF02509902

Alexander ED. 1989. Urban landslides. Progress in Physical Geography 13(2): 157-189. DOI: 10.1177/ 030913338901300201

Alexander ED. 2005. Vulnerability to landslides. In: Glade T, Anderson MG, Crozier MJ (eds.), Landslide risk assessment. John Wiley, 175-198.

Amadesi E, Vianello G. 1978. Nuova guida alla realizzazione di una carta di stabilità dei versanti. Memorie della Societa Geologica Italiana 19:53-60

Ardizzone F, Cardinali M, Galli M, Guzzetti F, Reichenbach P. 2007. Identification and mapping of recent rainfallinduced landslides using elevation data collected by airborne Lidar. Natural Hazards and Earth System Science 7: 637-650. DOI: 10.5194/nhess-7-637-2007

Ayalew L, Yamagishi H, Marui H, Kanno T. 2005. Landslides in Sado Island of Japan: Part II. GIS-based susceptibility mapping with comparisons of results from two methods and verifications. Engineering Geology 81: 432-445. DOI: 10.1016/j. enggeo.2005.08.004

Barbu N, Ungureanu A, Apăvăloaiei M, Băcăuanu V, Erhan E, Giosu V, Gugiuman I, Lupu-Bratiloveanu N, Martiniuc C, Nimigeanu V, Pantazică M, Poghirc P, Schram M, Șandu I, Ungureanu I. 1987. Iași Municipality geography. / Geografia Municipiului Iași. Editura Universității Alexandru Ioan Cuza din Iași, 311 p.

Barredo JI, Benavides A, Hervás J, van Westen CJ. 2000. Comparing heuristic landslide hazard assessment techniques using GIS in the Tirajana basin, Gran Canaria Island, Spain. International Journal of Applied Earth Observation and Geoinformation 2(1): 9-23. DOI: 10.1016/S0303-2434(00)85022-9

Băcăuanu V. 1968. Moldavian Plain - geomorphological study. / Cîmpia Moldovei. Studiu geomorfologic. Editura Univ. Al. I Cuza, Iași, 221 p. (in Romanian) 
Băcăuanu V. 1970. Landslides from north-eastern part of Copou Hillslope-Iași. / Alunecările de teren din partea nord-estică a Dealului Copou-Iași. Analele Științifice ale Universității Alexandru Ioan Cuza din Iași, serie nouă, Secțiunea II, 16: 143-146. (in Romanian)

Băcăuanu V, Barbu N, Pantazică M, Ungureanu A, Chiriac D. 1980. Moldavian Plateau. Nature, human, economy. / Podișul Moldovei. Natură, om, economie. Editura științifică și enciclopedică București, 345 p. (in Romanian)

Bejenaru A, Niculiță M. 2017. Landslide inventory of the Crasna catchment, Moldavian Plateau, Romania. In: Niculiță M, Mărgărint MC (eds.), Proceedings of Romanian Geomorphology Symposium, vol. 1. Editura Universității Alexandru Ioan Cuza, Iași, 28-31. DOI: $10.15551 /$ prgs.2017.28

Brabb EE. 1991. The world landslide problem. Episodes 14: 52-61.

Brânzilă M. 1999. Geology of the Moldavian Plain's southern part. / Geologia părții sudice a Câmpiei Moldovei. Editura Corson, Iași, 221 p. (in Romanian).

Carrara A. 1983. Multivariate models for landslide hazard evaluation. Mathematical Geology 15(3): 403-426. DOI: $10.1007 / B F 01031290$

Carrara A, Merenda L. 1976. Landslide inventory in northern Calabria, southern Italy. Geological Society of America Bulletin 87: 1153-1162. DOI:10. 1130/0016-7606(1976)87<1153:LIINCS>2.0.CO;2

Carrara A, Cardinali M, Detti R, Guzzetti F, Pasqui V, Reichenbach P. 1991. GIS techniques and statistical models in evaluating landslide hazard. Earth Surface Processes and Landforms 16: 427-445. DOI: 10.1002/esp.3290160505

Carrara A, Crosta G, Frattini P. 2003. Geomorphological and historical data in assessing landslide hazard. Earth Surface Processes and Landforms 28: 11251142. DOI: $10.1002 /$ esp.545

Castellanos Abela EA. 2008. Multi-scale landslide risk assessment in Cuba. International Institute for Geoinformation Science and Earth Observation, Enschede, The Netherlands. PhD Thesis.

Chung CF, Fabbri AG. 1999. Probabilistic prediction models for landslide hazard mapping. Photogrammetric Engineering and Remote Sensing 65(12): 1389-1399.

Chung CF, Fabbri AG. 2003. Validation of spatial prediction models for landslide hazard mapping. Natural Hazards 30: 451-472. DOI: 10.1023/B:NHAZ.0000007172.62651.2b

Conrad O, Bechtel B, Bock M, Dietrich H, Fischer E, Gerlitz L, Wehberg J, Wichmann V, Böhner J. 2015. System for Automated Geoscientific Analyses (SAGA) v. 2.1.4. Geoscientific Model Development 8: 1991-2007. DOI: 10.5194/gmd-8-1991-2015
Consiliul Județean Iași. 2012. Proiect de hotărîre privind declararea zonelor de risc la alunecări de teren de pe teritroiul administrative al Municipiului Iași.

Corominas J, Van Westen C, Frattini P, Cascini L, Malet JP, Fotopoulou S, Catani F, Van Den Eeckhaut M, Mavrouli O, Agliardi F, Pitilakis K, Winter MG, Pastor M, Ferlisi S, Tofani V, Hervás J, Smith JT. 2014. Recommendations for the quantitative analysis of landslide risk. Bulletin of Engineering Geology and the Environment 73: 209-263. DOI: 10.1007/s10064013-0538-8

Crozier MJ, Glade T. 2005. Landslide hazard and risk: issues, concepts and approach. In: Glade T, Anderson MG, Crozier MJ (eds.), Landslide risk assessment. John Wiley, 1-40.

Cruden DM. 1991. A simple definition of a landslide. Bulletin International Association of Engineering Geology 43: 27-29. DOI: 10.1007/BF02590167

Cruden DM, Eaton TM. 1987. Reconnaissance of rockslide hazards in Kananaskis Country, Alberta. Canadian Geotechnical Journa/24: 414-429. DOI: 10.1139/t87-052

Cruden DM, Varnes DJ. 1996. Landslide types and processes. In: Turner AK, Schuster RL (eds.), Landslides, investigation and mitigation. Special Report 247. Transportation Research Board, National Academy of Sciences, Washington DC, 36-75.

DeGraff JV. 1978. Regional landslide evaluation: two Utah examples. Environmental Geology 2(4): 203-214. DOI: 10.1007/BF02380486

Dill HG, Iancu GO, Ionesi V, Sârbu S, Balintoni I, Botz R. 2012. Petrography and mineral chemistry of Bessarabian siliciclastic rocks in the Eastern Carpathians Foreland Basin (Romania and Republic of Moldova). Neues Jahrbuch für Geologie und Paläontologie - Abhandlungen 263(3): 199-226. DOI: 10.1127/0077-7749/2012/0224

Ercanoglu M. 2005. Landslide susceptibility assessment of SE Bartin (Black Sea Region, Turkey) by artificial neural networks. Natural Hazards and Earth System Sciences 5: 979-992. DOI: 10.5194/nhess-5-979-2005

Gorsevski PV, Jankowski P, Gessler PE. 2006. A heuristic approach for mapping landslide hazard by integrating fuzzy logic with analytic hierarchy process. Control and Cybernetics 35(1): 121-146.

Guzzetti F. 2006. Landslide hazard and risk assessment. Bonn University. PhD thesis. http://hss.ulb.unibonn.de/2006/0817/0817.htm (Accessed 1 September 2017)

Guzzetti F, Carrara A, Cardinali M, Reichenbach P. 1999. Landslide hazard evaluation: a review of current techniques and their application in a multi-scale study, Central Italy. Geomorphology 31(1-4): 181216. DOI: 10.1016/S0169-555X(99)00078-1 
Landslide reactivation susceptibility modeling in Iași Municipality

Guzzetti F, Mondini AC, Cardinali M, Fiorucci F, Santangelo M, Chang KT. 2012. Landslide inventory maps: New tools for an old problem. Earth-Science Reviews 112: 42-66. DOI: 10.1016/j.earscirev. 2010.02.001

Hasekioğullari GD, Ercanoglu M. 2012. A new approach to use AHP in landslide susceptibility mapping: a case study at Yenice (Karabuk, NW Turkey). Natural Hazards 63(2): 1157-1179. DOI: 10.1007/s11069-0120218-1

Hungr O, Leroueil S, Picarelli L. 2014. The Varnes classification of landslide types, an update. Landslides 11: 167-194. DOI: 10.1007/s10346-013-0436-y

Hussin HY, Zumpano V, Reichenbach P, Sterlacchini S, Micu M, van Westen C, Bălteanu D. 2016. Different landslide sampling strategies in a grid-based bivariate statistical susceptibility model. Geomorphology 253: 508-523. DOI: 10.1016/j.geomorph.2015.10.030

Ionesi L. 1994. Geology of platform units and NordDobrogean Orogen. / Geologia unităților de platformă și a orogenului nord-dobrogean. Editura Tehnică, Bucharest, 280 p. (in Romanian)

Ionesi L, Ionesi B, Roșca V, Lungu A, Ionesi V. 2005. Middle and Upper Sarmatian on Moldavian Platform. / Sarmațianul mediu și superior de pe Platforma Moldovenescă. Editura Academiei Române 559 p (in Romanian)

Ioniță I. 2000. Cuesta landforms from Moldavian Plateau. / Relieful de cueste din Podișul Moldovei. Editura Corson, Iași, $103 \mathrm{p}$.

Jaboyedoff M, Oppikofer T, Abellán A, Derron M-H, Loye A, Metzger R, Pedrazzini A. 2012. Use of LIDAR in landslide investigations: a review. Natural Hazards 61: 5-28. DOI: 10.1007/s11069-010-9634-2

Jeanrenaud P, Saraiman A. 1995. Geology of Central Moldavia between the rivers Siret and Prut. / Geologia Moldovei Centrale dintre Siret și Prut. Editura Univ. Al. I Cuza, Iași, 186 p.

Kirschbaum DB, Adler R, Hong Y, Hill S, Lerner-Lam A. 2010. A global landslide catalog for hazard applications: method, results, and limitations. Natural Hazards 52: 561-575. DOI: 10.1007/s11069-0099401-4

Kjekstad O, Highland L. 2009. Economic and social impacts of landslides. In: Sassa K, Canuti P (eds.), Landslides - Disaster Risk Reduction. Springer, Verlag Berlin Heidelberg, 573-587.

Klose M. 2015. Landslide databases as tools for integrated assessment of landslide risk. Springer, Verlag Berlin Heidelberg, $156 \mathrm{p}$.

Leighton FB. 1976. Urban landslides: targets for land-use planning in California. In: Coates DR (ed.), Urban
Geomorphology. GSA Special Papers, 37-60. DOI: 10.1130/SPE174-p37

Macarovici N. 1942. Observations on the landslides from Iași in the 1942 spring. / Observațiuni asupra alunecărilor de teren de la Iași din primăvara anului 1942. Revista Științifică V. Adamachi 28(2-3): 1-4. (in Romanian)

Malamud BD, Turcotte DL, Guzzetti F, Reichenbach P. 2004a. Landslides, earthquake, and erosion. Earth and Planetary Science Letters 229: 45-59.

Malamud BD, Turcotte DL, Guzzetti F, Reichenbach P. 2004b. Landslide inventories and their statistical properties. Earth Surface Processes and Landforms 29: 687-711. DOI: 10.1002/esp.1064

Marc O, Hovius N. 2015. Amalgamation in landslide maps: effects and automatic detection. Natural Hazards and Earth System Scieces 15: 723-733. DOI: 10.5194/nhess-15-723-2015

Mark DM. 1983. Relations between field-surveyed channel networks and map-based geomorphometric measures, Inez, Kentucky. Annals of the Association of American Geographers 73: 358-372. DOI: 10.1111/j.1467-8306.1983.tb01422.x

Martiniuc C, Băcăuanu V. 1959. Geomorphological map of Iași city. / Harta geomorfologică a orașului Iași. Analele Științifice ale Universității Alexandru Ioan Cuza din Iași, serie nouă, Secțiunea II 5: 183-190. (in Romanian)

Martiniuc C, Băcăuanu V. 1966. Geomorphological studies of terraces from Bahlui catchment. / Cercetări geomorfologice asupra traselor din bazinul Bahluiului. Analele Științifice ale Universității Alexandru Ioan Cuza din Iași, serie nouă, Secțiunea II 12: 147-156. (in Romanian)

Martiniuc C, Băcăuanu V. 1982. Mass movements from Iași Municipality and its surroundings. / Deplasările de teren din municipiul Iași și împrejurimi. Buletinul Societății de Științe Geografice 6: 152-158. (in Romanian)

Mărgărint MC, Niculiță M. 2017. Landslide type and pattern in Moldavian Plateau, NE Romania. In: Rădoane M, Vespremeanu-Stroe A (eds.), Landform Dynamics and Evolution in Romania, Springer Geography, Springer Cham, 271-304. DOI: 10.1007/978-3-319-32589-7_12

McCalpin J. 1984. Preliminary age classification of landslides for inventory mapping. In: Proceedings of the Annual Symposium on Engineering Geology and Soil Engineering. University of Idaho, Idaho, 99-111.

McKean J, Roering J. 2004. Objective landslide detection and surface morphology mapping using highresolution airbone laser altimetry. Geomorphology 57: 331-351. DOI: 10.1016/S0169-555X(03)00164-8 
Meentemeyer RS, Moody A. 2000. Automated mapping of conformity between topographic and geological surfaces. Computers \& Geosciences 26: 815-829. DOI: 10.1016/S0098-3004(00)00011-X

Mondal S, Maiti R. 2012. Landslide susceptibility analysis of Shiv-Khola watershed, Darjiling: a remote sensing \& GIS based Analytical Hierarchy Process (AHP). Journal of the Indian Society of Remote Sensing 40(3): 483-496. DOI: 10.1007/s12524-011-0160-9

Necula N, Niculiță M, Tessari G, Floris M. 2017. InSAR analysis of Sentinel-1 data for monitoring landslide displacement of the north-eastern Copou hillslope, Iași city, Romania. In: Niculiță M, Mărgărint MC (eds.), Proceedings of Romanian Geomorphology Symposium, vol. 1. Editura Universității Alexandru Ioan Cuza, Iași, 85-88. DOI: 10.15551/prgs.2017.85

Niculiță M. 2011. A classification schema for structural landforms of the Moldavian platform (Romania). Geomorphometry 129-132, http://geomorphometry.org/system/files/Niculita201 1geomorphometry.pdf.

Niculiță M. 2012. A framework for the geomorphometric analysis of landforms from DEMs / Realizarea unui cadru de lucru pentru analiza geomorfometrică a reliefului reprezentat pe modelele numerice ale suprafeței terenului. Alexandru Ioan Cuza University of Iași. PhD thesis, http://www.geomorphologyonline. com/node/94. (in Romanian)

Niculiță M, Mărgărint MC. 2014. Landslide inventory for the Moldavian Plateau. In: Proceedings of International Conference Analysis and Management of Changing Risks for Natural Hazards, Padova. http://www.changes-

itn.eu/Portals/0/Content/2014/Final\%20conference/a bstracts/AP3_Abstract_Niculita.pdf, p 10

Niculiță M, Mărgărint MC, Santangelo M. 2016. Archeological evidence for Holocene landslide activity in the Eastern Carpathian lowland. Quaternary International 415: 175-189. DOI: 10.1016/j.quaint.2015.12.048

Niculiță M, Andrei A, Lupu C. 2017. The landslide database of the North-Eastern Romania. In: Niculiță $M$, Mărgărint MC (eds.), Proceedings of Romanian Geomorphology Symposium, vol. 1. Editura Universității Alexandru Ioan Cuza, Iași, 81-84. DOI: 10.15551/prgs.2017.81

Pánek T. 2015. Recent progress in landslide dating: a global overview. Progress in Physical Geography 39: 168-198. DOI: 10.1177/0309133314550671

Petley DN. 2009. On the impact of urban landslides. Geological Society, London, Engineering Geology Special Publications 22: 83-99. DOI: 10.1144/ EGSP22.6
Petschko H, Bell R, Glade T. 2015. Effectiveness of visually analyzing LiDAR DTM derivatives for earth and debris slide inventory mapping for statistical susceptibility modeling. Landslides 13(5): 857-872. DOI: 10.1007/s10346-015-0622-1

Pourghasemi HR, Pradhan B, Gokceoglu C. 2012. Application of fuzzy logic and analytical hierarchy process (AHP) to landslide susceptibility mapping at Haraz watershed, Iran. Natural Hazards 63(2): 965996. DOI: 10.1007/s11069-012-0217-2

R Development Core Team. 2008. $R$ : $A$ language and environment for statistical computing. R Foundation for Statistical Computing, Vienna. ISBN 3-900051-070; URL http://www.R-project.org.

Riley SJ, De Gloria SD, Elliot R. 1999. A terrain ruggedness that quantifies topographic heterogeneity. Intermountain Journal of Science 5(1-4): 23-27.

Rossi M, Guzzetti F, Reichenbach P, Mondini AC, Peruccacci S. 2009. Optimal landslide susceptibility zonation based on multiple forecasts. Geomorphology 114: 129-142. DOI: 10.1016/j. geomorph.2009.06.020

Rossi M, Ardizzone F, Cardinali M, Fiorucci F, Marchesini I, Mondini AC, Santangelo M, Ghosh S, Riguer DEL, Lahousee T, Chang KT, Guzzetti F. 2012. A tool for the estimation of the distribution of landslide area in $\mathrm{R}$. Geophysical Research Abstracts 14: EGU2012-9438-1.

Rozos DE, Bathrellos GD, Skillodimou HD. 2011. Comparison of the implementation of rock engineering system and analytic hierarchy process methods, upon landslide susceptibility mapping, using GIS: a case study from the Eastern Achaia County of Peloponnesus, Greece. Environmental Earth Sciences 63: 49-63. DOI: 10.1007/s12665-010-0687-z

Saaty TL. 1977. A scaling method for priorities in hierarchical structures. Journal of Mathematical Psychology 15: 234-281. DOI: 10.1016/00222496(77)90033-5

Saaty TL. 1980. The analytical hierarchy process, planning, priority setting, resource allocation. McGraw-Hill, New York, 287 p.

Saaty TL. 1987. The analytical hierarchy process - what it is and how it is used. Mathematical Modeling 9(3-5): 161-176. DOI: 10.1016/0270-0255(87)90473-8

Samia J, Temme A, Bregt A, Wallinga J, Guzzetti F, Ardizzone F, Rossi M. 2017. Do landslides follow landslides? Insights in path dependency from a multitemporal landslide inventory. Landslides 14(2): 547558. DOI 10.1007/s10346-016-0739-x

Saulea E, Săndulescu J, Bratu E. 1966. Geological map 1:200 000 / Harta geologică 1:200 000, 14 Iași, foaia L-35-X și L-35-XI. Comitetul de Stat al Geologiei, Institutul Geologic, București. 
Schram M, Pantazică M, Martiniuc C. 1977. Hydrogeological aspects of Iași Municipality and its surroundings. / Aspecte hidrogeologice din zona Municipiului Iași și împrejurimi. Analele Științifice ale Universității Alexandru Ioan Cuza din Iași, serie nouă, Secțiunea II 32: 107-113.

Schuster RL, Fleming RW. 1986. Economic losses and fatalities due to landslides. Bulletin of the Association of Engineering Geologists 23(1): 11-28. DOI: 10.2113/gseegeosci.xxiii.1.11

Soeters R, van Westen CJ. 1996. Slope instability recognition, analysis and zonation. In: Turner AK, Schuster RL (eds.), Landslides: investigation and mitigation. Special Report 247. Transportation research board, National Academy of Sciences, Washington DC, 129-177.

Ungureanu A. 1993. The geography of Romanian plateaus and plains./Geografia podisurilor și cimpiilor României. Editrua Universității Alexandru Ioan Cuza din Iași, 245 p. (in Romanian)

Van Den Eeckhaut M, Poesen J, Verstraeten G, Vanacker V, Moyersons J, Nyssen J, Van Beek LPH. 2005. The effectiveness of hillshade maps and expert knowledge in mapping old deep-seated landslides. Geomorphology 67: 351-363. DOI: 10.1016/j.geomorph.2004.11.001

Van Den Eeckhaut M, Reichenbach P, Guzzetti F, Rossi M, Poesen J. 2009. Combined landslide inventory and susceptibility assessment based on different mapping units: an example from the Flemish Ardennes, Belgium. Natural Hazards and Earth System Sciences 9: 507-521. DOI: 10.5194/nhess-9-507-2009

Van Westen CJ, Rengers N, Soeters R. 2003. Use of geomorphological information in indirect landslide susceptibility assessment. Natural Hazards 30(3): 399419. DOI: 10.1023/B:NHAZ.0000007097.42735.9e

Varnes DJ. 1978. Slope movement types and processes. In Schuster RL, Krizek RJ (eds.), Landslides, analysis and control. Special Report 176. Transportation research board, National Academy of Sciences, Washington DC, 11-33.

Varnes DJ, IAEG Commission on Landslides and other Mass-Movements. 1984. Landslide hazard zonation: a review of principles and practice. UNESCO Press, Paris, 63 p.

Wieczorek GF. 1984. Preparing a detailed landslideinventory map for hazard evaluation and reduction. Bulletin of the Association of Engineering Geologists 21(3): 337-342. DOI: 10.2113/gseegeosci.xxi.3.337

Wood J. 1996. The geomorphological characterisation of digital elevation models. University of Leicester. PhD thesis https://Ira.le.ac.uk/handle/2381/34503 (Accessed 1 September 2017)

Wood J. 2009. Geomorphometry in LandSerf. In: Hengl T, Reuter HI (eds.), Geomorphometry: Concepts, Software, Applications. Developments in Soil Science. Elsevier, 333-349.

Wu CH, Chen SC. 2009. Determining landslide susceptibility in Central Taiwan from rainfall and six site factors using the analytical hierarchy process method. Geomorphology 112: 190-204. DOI: 10.1016/j.geomorph.2009.06.002

Yalcin A. 2008. GIS-based landslide susceptibility mapping using analytical hierarchy process and bivariate statistics in Ardesen (Turkey): comparisons of results and confirmations. Catena 72: 1-12. DOI: 10.1016/j.catena.2007.01.003

Yoshimatsu H, Abe S. 2006. A review of landslide hazards in Japan and assessment of their susceptibility using an analytical hierarchic process (AHP) method. Landslides 3: 149-158. DOI: 10.1007/s10346-005$0031-y$

Záruba Q, Mencl V. 1982. Landslides and their control. Elsevier, $324 \mathrm{p}$. 